\title{
Characterization of Two Haemophilus somnus Fc Receptors
}

\author{
By MICHELE YARNALL, * RONALD P. GOGOLEWSKI AND \\ LYNETTE B. CORBEIL† \\ Department of Veterinary Microbiology and Pathology, Washington State University, Pullman, \\ Washington 99164-7040, USA
}

(Received 10 February 1988; revised 5 April 1988)

\begin{abstract}
Haemophilus somnus expresses two types of receptors that bind to the $\mathrm{Fc}$ region of bovine $\mathrm{IgG}$, $\operatorname{IgA}$ and $\operatorname{IgM}$. In this study, the relationship between these two types of $\mathrm{Fc}$ receptors is characterized. The high molecular mass receptors $(350,270$ and $120 \mathrm{kDa})$ were secreted into the culture medium and were also in the insoluble protein fraction of the culture medium. The $41 \mathrm{kDa} \mathrm{Fc}$ receptor, which is a major outer-membrane protein, was only present in the insoluble protein fraction. Peptide mapping of the two types of Fc receptors suggests that the $41 \mathrm{kDa}$ receptor is related to the high molecular mass receptor complex. Disulphide linkage is unlikely to be the mechanism of association of the $41 \mathrm{kDa}$ receptor with the high molecular mass receptors since reducing agents had no effect on separating the individual receptors. Although the $41 \mathrm{kDa}$ receptor is a major protein in the outer membrane of $H$. somnus, it does not react with convalescent bovine sera in Western blots. In contrast, convalescent bovine sera reacts intensely with the high molecular mass receptors in Western blots.
\end{abstract}

\section{INTRODUCTION}

Bacterial Fc receptors have been identified on staphylococci (Langone, 1982; Cox et al., 1986) and streptococci (Kronvall, 1973; Myrhe \& Kronvall, 1977, 1981; Reis et al., 1984; Yarnall \& Boyle, 1986) and more recently on three Gram-negative organisms, Brucella abortus (Nielsen et al., 1981), Taylorella equigenitalis (Widders et al., 1985) and Haemophilus somnus (Widders et al., 1988). The role of $\mathrm{Fc}$ receptors in host-parasite interactions is not understood. The staphylococcal $\mathrm{Fc}$ receptor, protein A promotes evasion of phagocytosis (Peterson et al., 1977; Dossett et al., 1969), and it has been postulated that other bacterial Fc receptors may be virulence factors (Christensen et al., 1977, 1978, 1981 ; Schalen, 1982; Ginsburg, 1972). We have recently identified and partially characterized two functionally distinct types of Fc receptors from $H$. somnus based on bovine Ig class reactivity (Yarnall et al., 1988). The receptor with a molecular mass of $41 \mathrm{kDa}$ bound weakly to both bovine IgG subclasses, IgA and IgM, while three high molecular mass receptors $(350,270$ and $120 \mathrm{kDa})$ strongly bound bovine $\mathrm{IgG}_{2}, \operatorname{IgA}$ and IgM. All of these Fc receptors were immunologically related (Yarnall et al., 1988).

Although $H$. somnus is a major cause of disease in both dairy and beef cattle, causing thromboembolic meningoencephalitis (TEME) (Bailie et al., 1966; Griner et al., 1956), pneumonia (Corbeil et al., 1986; Corstuet et al., 1973; Saunders et al., 1980), abortion (Corbeil et al., 1987; Chladek, 1975; Humphrey et al., 1982a,b) and probably infertility (Keister, 1981; Humphrey \& Stephens, 1983), virulence mechanisms and specific host defences are poorly understood. The persistence of $H$. somnus on the respiratory and genital mucosae (Humphrey et $a l ., 1982 a, b$; Slee \& Stephens, 1985; Ward et al., 1983), however, suggests that the organism can effectively evade the local defence mechanisms. Characterization of $H$. somnus $\mathrm{Fc}$ receptors is a

$\dagger$ Present address: Department of Pathology H811F, UCSD Medical Center, 225 Dickinson Street, San Diego, California 92103-1990, USA. 
prerequisite for determination of the potential roles of these receptors as bacterial virulence factors. Therefore, in this study, $H$. somnus Fc receptors were characterized according to location in the bacterial membrane, peptide mapping profiles and immunogenicity in cattle.

\section{METHODS}

Bacterial strain, media and growth conditions. Haemophilus somnus strain 2336 was used throughout this study. It was recovered from naturally occurring bovine pneumonia and subsequently used to produce experimental pneumonia (Gogolewski et al., $1987 a, b)$. Bacteria were frozen in $60 \%(\mathrm{v} / \mathrm{v})$ glycerol in $0.01 \mathrm{M}$-sodium phosphatebuffered isotonic (0.15 $\mathrm{M}$ ) saline, $\mathrm{pH} 7.4$ (PBS) at $-70^{\circ} \mathrm{C}$ after one subculture of the initial isolate. Bacteria were cultured at $37{ }^{\circ} \mathrm{C}$ in brain heart infusion broth (BHI, Difco) supplemented with $0.1 \%$ Tris and $0.001 \%$ thiamin monophosphate (BHI-TT) as described by Inzana \& Corbeil (1987), or were cultured on Columbia blood agar (CBA; Difco) plates made with $10 \%(\mathrm{v} / \mathrm{v})$ bovine blood or fetal bovine serum.

Preparation of the insoluble protein fraction of culture medium. H. somnus was grown in $300 \mathrm{ml} \mathrm{BHI-TT}$ broth for $8 \mathrm{~h}$ in a shaking water-bath at $37^{\circ} \mathrm{C}$. After centrifugation at $10000 \mathrm{~g}$ for $10 \mathrm{~min}$, the supernatant was filtered through a $0.45 \mu \mathrm{m}$ filter and centrifuged at $350000 \mathrm{~g}$ for $2 \mathrm{~h}$ at $4^{\circ} \mathrm{C}$ in a Beckman T150.2 rotor to sediment insoluble proteins. Pellets recovered from $300 \mathrm{ml}$ of culture were suspended in $2 \mathrm{ml}$ distilled water. The resulting supernatant was concentrated $50 \times$ by lyophilization and was reconstituted in $6 \mathrm{ml}$ distilled water.

Gel electrophoresis and Western blotting. Insoluble proteins $(25 \mu \mathrm{l})$ and supernatant $(30 \mu \mathrm{l})$ were analysed by electrophoresis under denaturing and reducing conditions in polyacrylamide gels containing SDS according to Laemmli (1970). In certain experiments no 2-mercaptoethanol or dithiothreitol was added. The separated proteins were electroblotted onto nitrocellulose (Towbin et al., 1979) and probed either with antisera prepared against the $H$. somnus $\mathrm{Fc}$ receptors or with convalescent bovine sera. Rabbit antibody was detected using peroxidaseconjugated goat anti-rabbit IgG (Kirkegaard and Perry Labs) and bovine antibody was detected with peroxidaseconjugated goat anti-bovine IgG (Cooper Biochemicals). The blots were developed with 4-chloro-1-naphthol $(0.05 \%)$ plus $\mathrm{H}_{2} \mathrm{O}_{2}(0.015 \%)$ in $16 \%$ (v/v) methanol.

Rabbit and bovine sera. Monospecific polyclonal antibodies to $H$. somnus $\mathrm{Fc}$ receptor proteins were prepared by inoculating rabbits or cattle with single antigen bands cut from SDS-PAGE as described previously (Yarnall et al., 1988). In brief, $H$. somnus 2336 insoluble protein pellets were applied to a $3.0 \mathrm{~mm}$ SDS-polyacrylamide gel and the gel was stained with $0 \cdot 2 \%$ Coomassie Brilliant Blue after electrophoresis. The $41 \mathrm{kDa}$ band, identified using molecular mass standards from a parallel gel, was cut from the gel and emulsified in approximately equal volumes of complete Freund's adjuvant for intramuscular inoculation into a cow. The bands from two preparative gels were given for each inoculation. Booster doses emulsified in incomplete Freund's adjuvant were given at monthly intervals with serum collected $10 \mathrm{~d}$ after each inoculation. The reactivity of the antisera was determined by Western blots of $H$. somnus insoluble protein pellets reacted with peroxidase-conjugated goat anti-bovine IgG (Cooper Biochemicals). Rabbits were immunized with either the $41 \mathrm{kDa}$ band or the $270 \mathrm{kDa}$ band in much the same way, except that the band from one gel was used for each rabbit.

Convalescent bovine sera were obtained from animals challenged experimentally with $H$. somnus. The clinical and isotypic antibody responses to these challenges have been described in earlier reports of experimental abortion (Widders et al., 1986) or pneumonia (Gogolewski et al., 1987b). Serum P3 was obtained from a cow in an experimental abortion study 6 weeks after intrabronchial inoculation of $10^{10}$ colony forming units (c.f.u.) of $H$. somnus isolate 649-4. Serum E5 was collected from a calf 5 weeks after intrabronchial inoculation of $10^{7}$ c.f.u. H. somnus isolate 2336 .

Limited proteolysis. Peptide maps were constructed by limited proteolysis using the procedure of Josefsson \& Randall (1983). Briefly, the $270 \mathrm{kDa}$ and $41 \mathrm{kDa}$ proteins were cut from an SDS-polyacrylamide gel, placed in the wells of another gel with 0.1 $\mu \mathrm{g}$ Staphylococcus aureus V8 protease (Miles Scientific) and electrophoresed into the stacking gel. Electrophoresis was then stopped for $45 \mathrm{~min}$ to allow digestion of the proteins which had been eluted from the gel piece. Electrophoresis was restarted and the peptides which were generated during the digestion were separated in the gel, electroblotted onto nitrocellulose, and probed with rabbit anti-41 kDa sera. The blot was developed as described above.

\section{RESULTS}

Release of $F c$ receptors into the culture supernatant. Our previous studies showed that $\mathrm{Fc}$ receptors are found in the supernatant of exponential phase $H$. somnus cultures (Yarnall et al., 1988). The initial effort of this study was to determine if both types of $F c$ receptors were secreted as soluble proteins directly into the medium or were sedimented with the insoluble protein fraction of the culture supernatant. Reacting these bacterial antigens with antisera specific for 


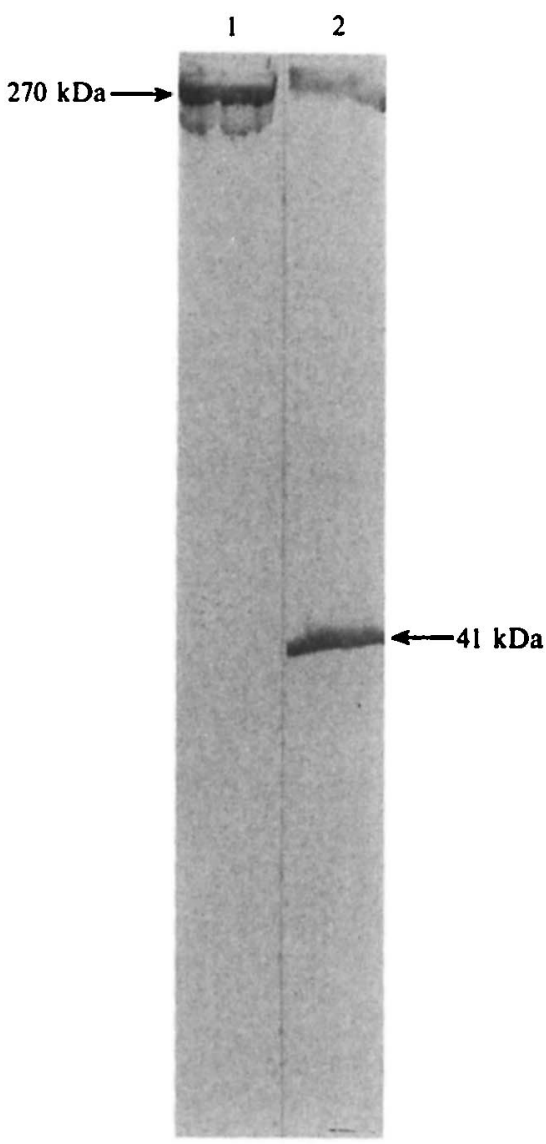

Fig. 1
1

2

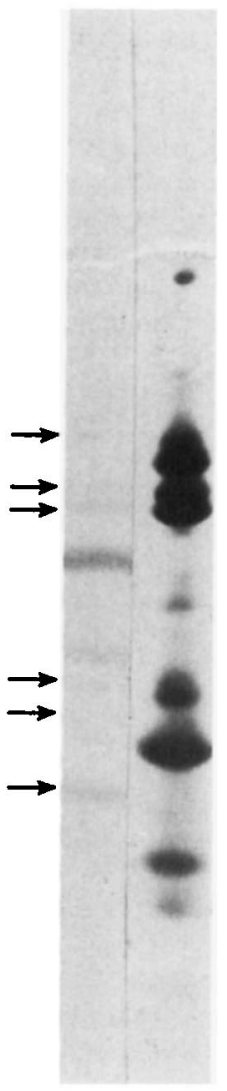

Fig. 2

Fig. 1. H. somnus $\mathrm{Fc}$ receptors in culture supernatant or insoluble pellet fraction. Culture supernatant concentrated $50 \times$ (lane 1) or insoluble pellet fraction (lane 2) were electrophoresed on an SDSpolyacrylamide gel containing 2-mercaptoethanol, electroblotted onto nitrocellulose, and probed with a mixture of rabbit anti-270 kDa (1/2000 dilution) plus rabbit anti-41 kDa sera (1/2000 dilution). Rabbit antibodies were detected with peroxidase conjugated goat anti-rabbit IgG (1/2000 dilution).

Fig. 2. Peptide maps of $H$. somnus $270 \mathrm{kDa}$ and $41 \mathrm{kDa} \mathrm{Fc}$ receptors. Peptides generated by Staphylococcus aureus V8 protease were detected by probing the nitrocellulose blot with rabbit anti$41 \mathrm{kDa}$ sera (1/1000 dilution) followed by peroxidase-conjugated goat anti-rabbit IgG (1/2000 dilution). Lane 1, $270 \mathrm{kDa}$ peptide profile. Lane 2, $41 \mathrm{kDa}$ peptide profile. Arrows indicate identically migrating peptides from both $\mathrm{Fc}$ receptors.

the $\mathrm{Fc}$ receptors revealed that the $41 \mathrm{kDa} \mathrm{Fc}$ receptor was found only in the insoluble protein pellet. However, the high molecular mass Fc receptors were detected both in the pellet and in the supernatant (Fig. 1).

Treatment with reducing agents. Since preliminary results suggested that the $41 \mathrm{kDa} F \mathrm{Fc}$ receptor may be a subunit or degradation product of the high molecular mass receptors (Yarnall et al., 1988), we determined the effect of reducing and non-reducing conditions on the $\mathrm{Fc}$ receptors: neither dithiothreitol nor 2-mercaptoethanol had any effect (results not shown).

Peptide mapping of Fc receptors. Peptide maps of the two types of $\mathrm{Fc}$ receptors probed with anti-41 kDa serum are shown in Fig. 2. Some antigenic peptides from the $270 \mathrm{kDa} F \mathrm{Fc}$ receptor (Fig. 2, lane 1) migrated identically to antigenic peptides from the $41 \mathrm{kDa} \mathrm{Fc}$ receptor (Fig. 2, lane 2); however, not all of the antigenic peptides detected in the $41 \mathrm{kDa}$ peptide profile were detected in the $270 \mathrm{kDa}$ peptide profile. No additional peptides in the $41 \mathrm{kDa}$ peptide profile 


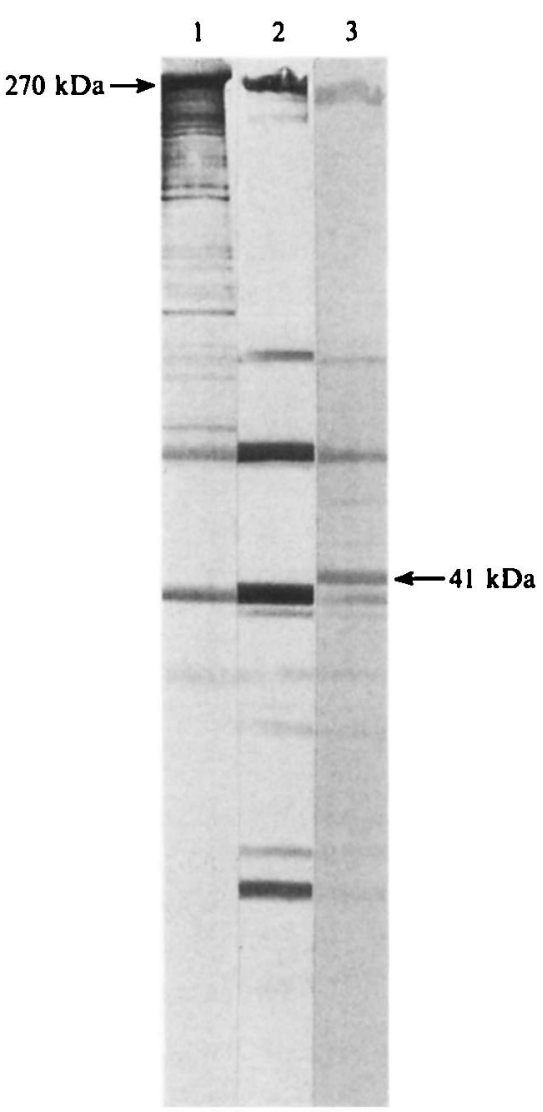

Fig. 3

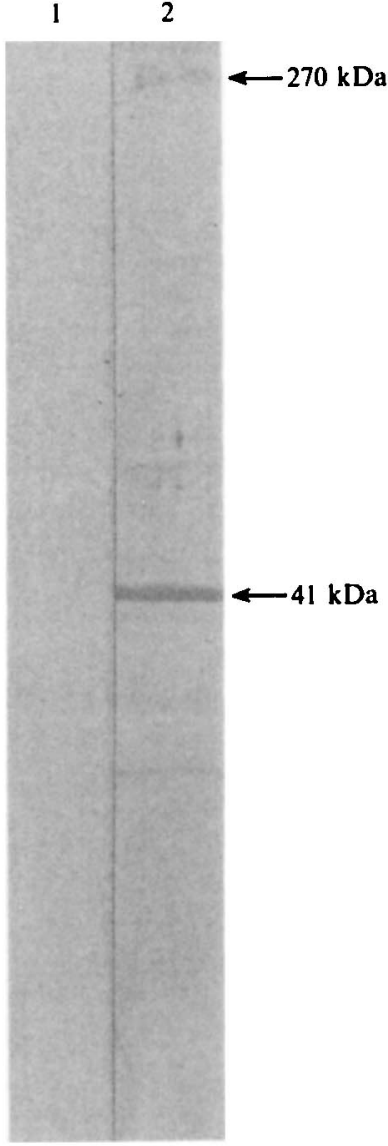

Fig. 4

Fig. 3. Detection of $\boldsymbol{H}$. somnus antigens using convalescent sera. $H$. somnus insoluble pellet fraction was electrophoresed on an SDS-polyacrylamide gel, electroblotted onto nitrocellulose, and probed with convalescent sera from a case of experimental abortion (lane 1) or from a case of experimental pneumonia (lanes 2 and 3). Lane 3 was counterstained with amido black for detection of proteins.

Fig. 4. Bovine anti-41 kDa serum activity. Antiserum prepared against the $41 \mathrm{kDa}$ Fc receptor was tested for reactivity with $H$. somnus insoluble pellet proteins by Western blot analysis. Blots were developed using peroxidase-conjugated goat anti-bovine IgG. Lane 1 , preimmune serum $(1 / 8000$ dilution); lane 2, anti-41 kDa serum (1/8000 dilution).

were detected when the nitrocellulose was stained with amido black. Some high molecular mass peptides $(>41 \mathrm{kDa})$ in the $270 \mathrm{kDa}$ peptide profile, however, were not detected with the anti$41 \mathrm{kDa}$ sera (data not shown).

Reactivity with convalescent sera. Detection of $H$. somnus antigens with convalescent bovine sera is shown in Fig. 3. Both abortion (lane 1) and pneumonia (lane 2) convalescent sera recognized the high molecular mass $F c$ receptors, but neither serum recognized the $41 \mathrm{kDa} F \mathrm{c}$ receptor even though it is a major protein in the insoluble protein pellet (lane 3).

Immunogenicity of the $41 \mathrm{kDa}$ Fc receptor in cattle. Although we have prepared antisera against the $41 \mathrm{kDa} \mathrm{Fc}$ receptor in rabbits (Yarnall et al., 1988), no antibody was detected in Western blots with serum from cattle previously infected or immunized with $H$. somnus. Therefore we immunized a cow to determine whether the protein itself is non-immunogenic in cattle. Fig. 4 shows the results of the immunization with the $41 \mathrm{kDa} F \mathrm{Fc}$ receptor. Antibody against the $41 \mathrm{kDa} F \mathrm{Fc}$ receptor was produced and this antiserum also reacted strongly with the high molecular mass receptors. 


\section{DISCUSSION}

Recently we demonstrated that the binding of bovine IgG subclasses $\operatorname{IgA}$ and $\operatorname{IgM}$ to $H$. somnus was a function of two distinct types of Fc receptors (Yarnall et al., 1988). One type consisted of a family of high molecular mass proteins (a $350 \mathrm{kDa}$ protein, a $270 \mathrm{kDa}$ protein, and a series of proteins in the 120 to $270 \mathrm{kDa}$ range) which bound strongly to bovine $\operatorname{IgG}_{2}, \operatorname{IgA}$ and IgM. The other type of $F c$ receptor (a $41 \mathrm{kDa}$ protein) bound weakly to bovine $\operatorname{IgG}_{1}, \operatorname{IgG}_{2}, \operatorname{IgA}$ and IgM. In this report, we have further characterized these two types of Fc receptors. The high molecular mass $\mathrm{Fc}$ receptors were present in the culture medium in both soluble and insoluble forms (Fig. 1), whereas the $41 \mathrm{kDa} \mathrm{Fc}$ receptor was found only in the insoluble portion of the supernatant. Although we hypothesized that the $41 \mathrm{kDa}$ protein may be a subunit of the high molecular mass proteins, treatment with reducing agents had no effect on any of the Fc receptors. The peptide profiles of the two types of Fc receptors, however, suggested that the $41 \mathrm{kDa} F \mathrm{~F}$ receptor is related to the high molecular mass receptor since digestion of the $270 \mathrm{kDa}$ Fc receptor produced peptides which migrated identically and were antigenically related to peptides from the digestion of the $41 \mathrm{kDa} \mathrm{Fc}$ receptor (Fig. 2). Digestion of the $270 \mathrm{kDa}$ protein was always less efficient than digestion of the $41 \mathrm{kDa}$ protein even if the concentration of protease was increased. Therefore, the apparently weak reactivity of the peptides from the $270 \mathrm{kDa} F \mathrm{c}$ protein (Fig. 2) probably reflects the low concentration of peptides which were generated, rather than a lower affinity per se.

Although the $41 \mathrm{kDa} F \mathrm{c}$ receptor appears to be a major protein in the insoluble protein pellet of $H$. somnus (Fig. 3), and is immunogenic in rabbits and cattle as a purified protein from an SDS polyacrylamide gel (Fig 4), it fails to react with sera from animals convalescing from $H$. somnus disease (Fig. 3). This result is in keeping with those of our previous studies, when we found no reactivity with the 41 antigen among five out of five sera from cattle with experimental pneumonia (Gogolewski et al., 1987b), and eighteen out of eighteen cattle with abortion (Corbeil et al., 1987), or one cow hyperimmunized with whole formulized $H$. somnus (Corbeil et al., 1987). The reason for the recognition of the high molecular mass Fc receptors, but not the $41 \mathrm{kDa} F \mathrm{c}$ receptor by convalescent bovine sera (Fig. 3) is not known. The $41 \mathrm{kDa}$ protein may not be immunogenic in cattle infected or immunized with $H$. somnus because the protein is not exposed in the outer membrane. This would be consistent with the lack of shedding of soluble $41 \mathrm{kDa}$ protein into the supernatant. However, it may also be that the $41 \mathrm{kDa}$ protein was denatured by boiling in SDS prior to SDS-PAGE and excision of the band from the gel in our immunization studies with gel purified protein. The denatured protein may be immunogenic whereas the native protein may not be immunogenic. Whatever the reason for lack of an immune response to the $41 \mathrm{kDa}$ protein by infected animals, the lack of response may be significant in bacterial evasion of the host response. Since antibody to $H$. somnus enhances phagocytosis (Czuprinski \& Hamilton, 1985) and protects against experimental pneumonia (Gogolewski et al., 1987), failure of this major membrane protein to stimulate a humoral response during the course of an infection may enhance bacterial survival in vivo. Further studies are in progress to characterize the biological activities of these Fc receptors, to determine their distribution among $\boldsymbol{H}$. somnus strains, and to establish if the presence of these receptors plays any role in the pathogenesis of $H$. somnus.

\section{REFERENCES}

Bailie, W. E., ANTHONY, H. D. \& Weide, K. D. (1966). Infectious thromboembolic meningoencephalitis (sleeper syndrome) in feedlot cattle. Journal of the American Veterinary Medical Association 148, 162166.

ChladeK, D. W. (1975). Bovine abortion associated with Haemophilus somnus. American Journal of Veterinary Research 36, 1041.

Christensen, P., Sjoholm, A. G. \& Holm, S. E. (1977). Binding of aggregated IgG to nephritogenic type 12 streptococci: influence of serum, $\mathrm{C}_{1}$ and $\mathrm{C}_{4}$. Acta pathologica microbiologica scandinavica 85, 359366.

Christensen, P., SJoholm, A. G., Holm, S. E., Hovelius, B. \& Mardh, P. A. (1978). Binding of aggregated $\mathrm{IgG}$ in the presence of fresh serum by group A streptococci producing pharyngeal infection: possible connection with types frequently involved in acute nephritis. Acta pathologica microbiologica scandinavica 86, 29-33. 
Christensen, P. J., Sramek, J. \& Zatterstrom, U. (1981). Binding of aggregated IgG in the presence of fresh serum: strong association with type 12 group $A$ streptococci. Acta pathologica microbiologica scandinavica 89, 87-91.

Corbeil, L. B., Widders, P. R., Gogolewski, R. P., ARTHUR, J., INZANA, T. J. \& WARD, A. C. S. (1986). Haemophilus somnus: bovine reproductive and respiratory disease. Canadian Veterinary Journal 27, 90-94.

Corbeil, L. B., Arthur, J. E., Widders, P. R., Smith, J. W. \& BARBET, A. F. (1987). Antigenic specificity of convalescent serum from cattle with Haemophilus somnus-induced experimental abortion. Infection and Immunity 55, 1381-1386.

Corstvet, R. E., Panciera, R. J., Rinker, H. B., STARKS, B. L. \& Howard, C. (1973). Survey of tracheas of feedlot cattle for Haemophilus somnus and other selected bacteria. Journal of the American Veterinary Medical Association 163, 870-873.

Cox, H. V., Schmeer, N. \& Newman, S. S. (1986). Protein A in Staphylococcus intermedius isolates from dogs and cats. American Journal of Veterinary Research 47, 1881-1884.

Czuprinski, C. J. \& Hamilton, H. J. (1985). Bovine neutrophils ingest but do not kill Haemophilus somnus. Infection and Immunity 50, 431-436.

Dossett, J. H., Kronvall, G., Williams, R. C. \& QUIE, P. G. (1969). Antiphagocytic effects of staphylococcal protein A. Journal of Immunology 103, 1405-1410.

GinsBurG, I. (1972). Mechanisms of cell and tissue injury induced by group A streptococci: relation to poststreptococcal sequelae. Journal of Infectious Diseases 126, 419-456.

Gogolewski, R. P., Kania, S. A., Inzana, T. J., Widders, P. R., LiggitT, H. D. \& CORBEIL, L. B. $(1987 a)$. Protective ability and specificity of convalescent serum from calves with Haemophilus somnus pneumonia. Infection and Immunity 55, 1403-1411.

Gogolewski, R. P., Leathers, C. W., Liggitt, H. D. \& CorbeIL, L. B. $(1987 b)$. Experimental Haemophilus somnus pneumonia in calves and immunoperoxidase localization of bacteria. Veterinary Pathology 24, 250-256.

Griner, L. A., Jensen, R. \& Brown, W. W. (1956). Infectious embolic meningoencephalitis in cattle. Journal of the American Veterinary Medical Association 129, 417-421.

Humphrey, J. D. \& Stephens, L. R. (1983). Haemophilus somnus: a review. Veterinary Bulletin 53, 987 1004.

Humphrey, J. D., Little, P. B., Stephens, L. R., Barnum, D. A., Doig, P. A. \& Thorsen, J. (1982a). Prevalence and distribution of Haemophilus somnus in the male bovine reproductive tract. American Journal of Veterinary Research 43, 791-795.

Humphrey, J. D., LitTle, P. B., Barnum, D. A., Doig, P. A., Stephens, L. R. \& ThORSEN, J. (1982b). Occurrence of Haemophilus somnus in bovine semen and in prepuce of bulls and steers. Canadian Journal of Comparative Medicine 46, 215-217.

INZANA, T. J. \& CORBEIL, L. B. (1987). Development of a defined media for Haemophilus somnus isolated from cattle. American Journal of Veterinary Research 48, 366-369.
Josefsson, L. \& Randall, L. L. (1983). Analysis of cotranslational proteolytic processing of nascent chains using two dimensional gel electrophoresis. Methods in Enzymology 97, 77-85.

KESITER, D. M. (1981). Haemophilus somnus infections in cattle. Compendium Continuing Education for the Practicing Veterinarians 3, S260-S264.

KRONVALL, G. (1973). A surface component in group $A, C$, and $G$ streptococci with non-immune reactivity for IgG. Journal of Immunology 111, 1401-1406.

LAEMMLI, U. K. (1970). Cleavage of structural proteins during the assembly of the head of bacteriophage T4. Nature, London 227, 680-685.

Langone, J. J. (1982). Protein A from Staphylococcus aureus and related immunoglobulin receptors produced by streptococci and pneumococci. Advances in Immunology 32, 157-252.

MYRhe, E. B. \& Kronvall, G. (1977). Heterogeneity of non-immune immunoglobulin Fc-reactivity among Gram positive cocci: description of three major types of receptors for human IgG. Infection and Immunity 17, 475-482.

MYRHE, E. B. \& KRONVALl, G. (1981). Immunoglobulin specification of defined types of streptococcal Ig receptors. In Basic Concepts of Streptococci and Streptococcal Diseases, pp. 209-210. Edited by S. E. Holm \& P. Christensen. Chertsey, UK: Reed Publications.

Nielsen, K., Stilwell, K., Stemshorn, B. \& DuNCAN, R. (1981). Ethylenediaminetetraacetic acid (disodium salt)-labile bovine immunoglobulin $\mathrm{M} \mathrm{Fc}$ binding to Brucella abortus: a cause of nonspecific agglutination. Journal of Clinical Microbiology 14, 32-38.

Peterson, P. K., Nerhoef, Journal., Sabath, L. D. \& QuiE, P. G. (1977). Effect of protein A on staphylococcal opsonization. Infection and Immunity 15, 760-764.

Reis, K. J., Ayoub, E. M. \& Boyle, M. D. P. (1984). Streptococcal Fc receptors. I. Isolation and partial characterization of the receptor from a group $\mathrm{C}$ streptococcus. Journal of Immunology 132, 30913097.

Saunders, J. R., Thiessen, W. A. \& Janzen, E. D. (1980). Haemophilus somnus infection. I. A ten year (1969-1978) retrospective study of losses in cattle herds in western Canada. Canadian Veterinary Journal 21, 119-123.

SCHALEN, C. (1982). Immunoglobulin receptors of group A streptococci: their specificity and importance for virulence. PhD thesis, University of Lund.

SLeE, K. J. \& Stephens, L. R. (1985). Selective medium for isolation of Haemophilus somnus from cattle and sheep. Veterinary Records 116, 215-217.

Towbin, H., Staehelin, T. \& Gordon, J. (1979). Electrophoretic transfer of proteins from polyacrylamide gels to nitrocellulose. Proceedings of the National Academy of Sciences of the United States of America 76, 4350-4354.

Ward, A. C. S., Corbeil, L. B., Mickelson, W. D. \& SweET, V. F. (1983). A selective medium for Gramnegative pathogens from bovine respiratory and reproductive tracts. American Association of Veterinary Laboratory Diagnostics 26, 103-112.

Widders, P. R., STOKes, C. R., Newby, T. J. \& BOURNE, F. J. (1985). Non-immune binding of 
equine immunoglobulin by the causative organism of contagious equine metritis (Taylorella equigenitalis). Infection and Immunity 48, 417-421.

Widders, P. R., Paisley, L. G., Gogolewski, R. P., Evermann, J. F., Smith, J. F. \& Corbeil, L. B. (1986). Experimental abortion and the systemic immune response in cattle to Haemophilus somnus. Infection and Immunity 54, 555-560.

Widders, P. R., DoWling, S. C., SMITH, J. N., YaRNALl, M., MCGuiRe, T. \& CoRBEIL, L. B. (1988). Non-immune immunoglobulin binding by
Haemophilus somnus. Journal of Medical Microbiology (in the Press)

YARNALL, M. \& BoYLE, M. D. P. (1986). Isolation and characterization of type IIa and type IIb Fc receptors from a group A Streptococcus. Scandinavian Journal of Immunology 24, 549-557.

YaRNALl, M., Widders, P. R. \& CoRbeIL, L. B. (1988). Isolation and characterization of Fc receptors from Haemophilus somnus. Scandinavian Journal of Immunology (in the Press). 